\title{
The epidemiology of $Q$ fever
}

\author{
R. J. C. HART \\ M.B., M.R.C.Path.
}

\section{Public Health Laboratory, Church Lane, Heavitree, Exeter EX2 5AD}

\begin{abstract}
Summary
$Q$ fever was first described in Australia and has since been reported from many countries. Rickettsia burneti infects numerous species of mammals and has been isolated from ticks. Infected cattle, sheep and goats remain healthy but excrete the organism, which is present in high concentration in products of conception and survives in dust for long periods. The ways in which humans may become infected are considered. Many of these infections do not cause symptoms, but some are fatal and the prevention of this disease remains a challenge.
\end{abstract}

THE term Q (or query) fever was coined by Derrick (1937), who had been called upon in 1935 to investigate a febrile illness that had affected some twenty out of 800 employees of a large Brisbane meat works during the previous 2 years. From an investigation of nine more patients, he isolated an organism which was identified as a rickettsia by Burnet \& Freeman (1937). Almost simultaneously, Davis \& Cox (1938) isolated an organism in the United States from ticks, Dermacentor andersoni, and named it Rickettsia diapora. The two organisms were subsequently shown to be identical and are now known as Rickettsia (or Coxiella) burneti.

\section{Geographical distribution}

Derrick (1944) reported a further 176 cases of $Q$ fever associated with the meat and dairy industries in Queensland, and Hansman, Wannan \& Woolard (1966) found evidence of infection in abattoir workers in New South Wales. They reported higher incidence in those who handled cattle from Queensland. $Q$ fever was first reported in the Northern Hemisphere among troops in Italy during the second world war and antibodies were found in the sera of members of the indigenous population (Robbins, Gauld \& Warner, 1946). The presence of $\boldsymbol{R}$. burneti in North America has already been mentioned. At the time of its discovery, it appears to have been limited to the southern parts of the continent, where Topping, Shepard \& Irons (1947) reported an explosive outbreak of $Q$ fever in a stockyard and slaughterhouse in Texas and Shepard \& Huebner (1948) found it in California. Serological surveys of man and cattle indicate that it spread northwards during the 1950's, reaching Maryland in 1959 (Wagstaff et al., 1965) and British Columbia at about the same time (McKeil, 1964). The distribution of the disease now appears to be world wide. In Britain it was first reported by MacCallum, Marmion \& Stoker in 1949. At that time $R$. burneti was demonstrated in cattle in Kent and Devon to account for these infections (Marmion \& Stoker, 1950). Marmion et al. (1953) reported cases of $Q$ fever over a wide area of England and Wales, and its presence in Scotland was first demonstrated by the finding of antibody in a child in 1953 (Grist, 1954).

$R$. burneti reached Northern Ireland between 1957 and 1962, probably as a result of the importation of infected ewes from England (Connolly, 1968), and the Republic of Ireland at about the same time, though the first known case of $Q$ fever there seems to have occurred in 1966 (Hillary, Shattock \& Meenan, 1971).

\section{Infection in animals}

$R$. burneti, like some other rickettsiae, undergoes a wildlife cycle in arthropods and vertebrates. Derrick (1937) suspected that there might be 'a reservoir of infection in some animal with a bloodsucking parasite as vector'. He went on later to postulate (Derrick, 1944) that there was a basic cycle in bandicoots and ticks. Cattle were infected by these ticks and in turn conveyed $R$. burneti to other species of tick. He suggested that human infections were the result of inhalation of tick faeces. Numerous other workers have studied the wildlife cycle of $R$. burneti and have shown that it infects ticks associated with a variety of rodents, kangaroos (Johnson, 1966), cattle and sheep. Enright et al. (1971a) found antibodies to $R$. burneti in birds collected on a sheep range, but considered that the birds were probably infected by feeding on dead sheep or placentae. There is some doubt about the significance of this wildlife cycle in the maintenance and spread of the organism. Enright et al. (1971b) considered that $R$. burneti released in large numbers at parturition by sheep provided a source of wildlife infection, and found no evidence that sheep were infected from the wildlife cycle. Hrabar et al. (1971) showed that wildlife infection was introduced into 
a previously uninfected territory in Yugoslavia by travelling flocks of sheep. There is also evidence that sheep may play a part in infecting cattle (Marmion \& Stoker, 1958). It seems probable that wildlife infections are not responsible for the spread of $\boldsymbol{R}$. burneti to new territories, though they may be able to maintain it once it has been established in an area. The wildlife cycle may play a part in the infection of farm animals by ticks, though Stoker \& Marmion (1955) were sceptical about the role of the tick in the transmission of $R$. burneti to sheep in Romney Marsh.

Cattle, sheep and goats, the domestic animals implicated in human $\mathbf{Q}$ fever, show no evidence of ill health when infected with $R$. burneti and give birth to normal young. However, the placenta and birth fluids of an infected animal contain enormous numbers of rickettsiae. Welsh et al. (1951) found $10^{9}$ guinea-pig infective doses per gram of sheep placenta. The organisms may contaminate litter or fleece and survive for long periods. Stoker et al. (1955) found that wool from the perineum of an infected ewe contained almost as many rickettsiae as its placenta.

\section{$Q$ fever in man}

$Q$ fever in man is predominantly, and with few exceptions, the result of direct or indirect contact with infected animals. This may occur at parturition or indirectly from a contaminated environment. Since a great many infections by $R$. burneti are occupational, the preponderance of male patients of working age reported by numerous authors is not surprising, but Johnson (1966) reported Q fever in a child of 8 months who was taken into Australian shearing sheds.

Direct human infection at the time of delivery of animals is illustrated by the veterinary surgeon and his assistant in an endemic area who developed $Q$ fever 3 weeks after they had manually removed the placentae of two cows (Marmion et al., 1953). A family outbreak in which the source of infection was probably a sheep placenta brought into the house by a dog (Connolly, 1968) is a bizarre illustration of the risk of infection from the products of parturition. Clarke, Lennette \& Romer (1951) reported cases of 'goat-boat fever' in the crews of ships carrying goats across the Pacific. The goats were pregnant and many kids were born during the voyages. Serological investigations showed that the disease was $Q$ fever and that many goats had been infected. It is also known that where sheep rearing is practised, the incidence of $\mathbf{Q}$ fever is highest after lambing. This was the case in Cyprus during the troubles in the late 1950's, where cases of $Q$ fever occurred in the spring and early summer among British troops who lived rough on patrol.
Much experimental and epidemiological evidence points to infection being acquired from contaminatedळ dust.

Allied troops serving in Italy and Greece in the

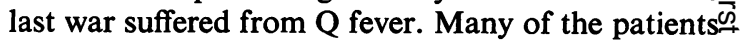
had slept in barns or lofts and used dusty hay orc straw for bedding. Some of their accommodation $\overline{\bar{O}}$. had been used previously for livestock. One explosive $\frac{\bar{s}}{\odot}$ outbreak occurred in a unit that used a large hayloft $\stackrel{\circ}{\circ}$ above a cattle barn for the showing of training films to whole companies at a time. The men sat on bales of dusty hay and the dust must have been heavily: contaminated with $R$. burneti, as 269 soldiers out of $\vec{\omega}$ a total strength of approximately 900 developed 'primary atypical pneumonia' during a period of 3 weeks, reckoned from 16 days after the first film 3 show. $R$. burneti was isolated from the blood of six $\overrightarrow{0}$ patients and rising titres of antibody were found incy twenty-nine out of the thirty pairs of sera examined + (Robbins et al., 1946).

Straw was implicated in the outbreak at the Canterbury College of Art (Harvey, Forbes \& Marmion, 1951) in which there were twenty-eight cases. About 19 days before the outbreak, an old packing case containing mouldy and dusty straw was used to make a crate for a statue that was packed $\stackrel{\text { ? }}{+}$ in the straw and sent to London. A woman wis $\overrightarrow{0}$ unpacked the statue was ill about 2 weeks later, a antibody to $R$. burneti was subsequently found her serum. The straw was not available for examinattion by the time the outbreak was investigated.

Circumstantial evidence has suggested the possibility of down-wind spread of the agent from

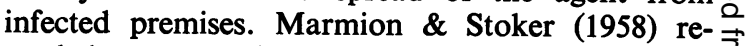
corded a group of ten patients in a small town in north Kent who lived or worked near a fertilizer $\vec{J}$ factory that received offal from abattoirs in Kent and Sussex. After an animal was slaughtered, material such as the uterus, placenta with birth fluids, and intestines which might have contained $R$. burneti were sent to the factory. Whether an aerosol con- 3 . taining rickettsiae was produced in the factory or whether the organism was liberated in areas visited by the patients from dust carried out of the factory 0 was not established. $R$. burneti has, however, been recovered from the air of buildings in which cattle, 음 sheep or goats had been housed (Lennette \& Welsh, 1951). Recent work on the airborne dispersal of $O$ foot and mouth disease virus suggests that it may be $N$ blown some distance by the wind before giving rise to infection by inhalation when climatic conditions 0 are suitable (Sellers \& Herniman, 1972). It may be that $R$. burneti, which is better able to withstand drying, may travel in the same way. Tigertt, Benenson \& Gochenour (1961) considered that a single rickettsia was capable of initiating infection, so it is possible that small numbers of airborne organisms 
blown some distance from a point of origin could cause infection in susceptible individuals.

Milk has been implicated as a vehicle of infection. Marmion \& Stoker (1958) reported a higher incidence of $\mathbf{Q}$ fever and of serum antibodies in people who drank raw milk, some of which was infected with $R$. burneti, than among consumers of pasteurized milk. Brown, Colwell \& Hooper (1968) reported an explosive outbreak of $Q$ fever in a detention centre in Staffordshire as the first milk-borne outbreak in this country. Twenty-nine inmates and staff were ill, and rising titres of complement fixing antibody to $R$. burneti were found in seven out of eight paired sera. Antibodies were also demonstrated in eleven out of fourteen convalescent sera. The centre had a farm attached and the milk used was from cows on this farm. $R$. burneti was found in the milk of two of the cows and antibody in the sera of three others. None of the patients had been in contact with the animals during the 3 weeks before the outbreak started.

Little need be said of other routes of infection in man. Human infection by tick bites does not seem to occur, and while Derrick's theory of the inhalation of infected tick faeces as a source of infection for man has not been disproved, other prolific sources of $R$. burneti are evident. Laboratory infections are usually ascribed to the inhalation of $R$. burneti, though in a review of fifty laboratoryacquired infections Johnson \& Kadull (1966) recorded one patient who accidentally inoculated the organism into himself and had a lesion at the site of inoculation. Workers infected in laboratory outbreaks have included office staff who had not entered the room in which work with $R$. burneti was being done. Case-to-case transmission of $Q$ fever is so uncommon as to render isolation of patients unnecessary. However, the outbreak at the Royal Cancer Hospital (Harman, 1949) in which a nurse, two pathologists and a mortuary attendant developed $Q$ fever after dealing with a fatal case, demonstrated the risk of infection by this route and the danger of aerosols produced at necropsy (MacCallum, Marmion \& Stoker, 1949).

\section{Surveillance of $\mathbf{Q}$ fever in the community}

Outbreaks of $Q$ fever have commanded attention because of their explosive character and the high incidence of disease. Forty per cent of the staff of a stockyard and slaughterhouse at Amerillo, Texas, developed $\mathbf{Q}$ fever over a period of 9 days (Topping et al., 1947). Such incidents are the result of the first exposure of a population to $R$. burneti. By contrast, in a comparable situation in an abattoir in Adelaide, where the disease was endemic, cases of $Q$ fever occurred over a period of 8 months, with an attack rate of $6 \%$. Attempts to trace the sources of infection of individual cases were largely unsuccessful (Beech, Duxbury \& Warner, 1962).

Although many laboratories carry out complement fixation tests, only fifty to seventy sporadic cases are diagnosed annually in Britain, and the source of the infective agent is seldom found. In an endemic area like Devon, where 20 years ago $R$. burneti was found in the milk of $2.7 \%$ of herds of cattle (Marmion et al., 1953), the indigenous population might be expected to have some immunity to $Q$ fever. This could explain why, of the last nine cases diagnosed at the Public Health Laboratory, Exeter, seven were adults who had moved to rural areas of Devon from large towns elsewhere.

It is hardly surprising that it is difficult to draw a detailed picture of the disease in communities where it is endemic. The causative agent is excreted by healthy animals and can persist in dust for long periods.

Many individuals develop antibody without evidence of disease, and studies of blood donors in many parts of the world have shown a higher incidence of infection by $R$. burneti than of clinical $Q$ fever. The demonstration of antibody in a number of young children suffering from other diseases in Devon hospitals prompted a study in an area in which raw milk containing $R$. burneti was still readily available. Groups of children attendinge clinics for routine immunization were bled; sera were examined for complement fixing antibodies to the phase 2 antigen of $R$. burneti. Antibody was found in three out of 125 children aged 4-12 months and 7 out of 121 aged 4-5 years. While this investigation was going on, a brucella eradication scheme was in progress. At the outset raw milk was supplied from fourteen herds and $R$. burneti was present in samples from six of them. When the investigation finished, $R$. burneti was found in milk samples from three of the nine herds still supplying raw milk.

The eradication of Brucella abortus from cattle may incidentally result in the consumption of less raw milk contaminated with $R$. burneti. However, there is little likelihood that any attempt will be made to eradicate this organism from farm livestock because infected animals remain healthy. They can therefore be expected to continue to contaminate their environment with an organism which is capable of causing serious and sometimes fatal disease in man. Our understanding of $\mathbf{Q}$ fever with a view to its prevention remains a challenge.

\section{References}

Beech, M.D., DuXbury, A.E. \& W ARner, P. (1962) Q fever in South Australia: an outbreak in a meat-works. Journal of Hygiene, 60, 1.

Brown, G.L., Colwell, D.C. \& Hooper, W.L. (1968) An outbreak of $\mathrm{Q}$ fever in Staffordshire. Journal of Hygiene, 66,649 . 
Burnet, F.M. \& Freeman, M. (1937) Experimental studies on the virus of Q fever. Medical Journal of Australia, 2, 299.

Clarke, W.H., Lennette, E.H. \& Romer, M.S. (1951) $Q$ fever in California. IX. An outbreak aboard a ship transporting goats. American Journal of Hygiene, 54, 35.

CoNNOLLY, J.H. (1968) $Q$ fever in Northern Ireland. British Medical Journal, 1, 547.

DAvis, G.E. \& Cox, H.R. (1938) A filter-passing infectious agent isolated from ticks. I. Isolation from Dermacentor andersoni, reactions in animals, and filtration experiments. Public Health Reports, 53, 2259.

DerRICK, E.H. (1937) $Q$ fever, a new fever entity: clinical features, diagnosis and laboratory investigation. Medical Journal of Australia, 2, 281.

DERRICK, E.H. (1944) The epidemiology of Q fever. Journal of Hygiene, 43, 357.

ENRIGHT, J.B., LONGHURST, W.M., Wright, M.E., Dutson, V.J., Franti, C.E. \& Behymer, D.E. (1971a) Q fever antibodies in birds. Journal of Wildlife Disease, 7, 14.

Enright, J.B., Franti, C.E., Longhurst, W.M., Behymer, D.E., Wright, M.E. \& Dutson, V.J. (1971b) Coxiella burneti in a wildlife-livestock environment. Antibody response of ewes and lambs in an endemic $Q$ fever area. American Journal of Epidemiology, 94, 62.

GRIST, N.R. (1954) Virus pneumonia in Glasgow. Lancet, i, 650.

Hansman, D., Wannan, J.S. \& Woolard, T.J. (1966) Q fever, brucellosis and leptospirosis among abattoir workers in New South Wales. Medical Journal of Australia, 2, 20.

HARMAN, J.B. (1949) Q fever in Great Britain : clinical account of eight cases. Lancet, ii, 1028.

HaRvey, M.S., Forbes, G.B. \& Marmion, B.P. (1951) An outbreak of $Q$ fever in East Kent. Lancet, ii, 1152.

Hillary, I.B., Shattock, A.G. \& Meenan, P.N. (1971) The incidence of $\mathbf{Q}$ fever in the Republic of Ireland. Journal of the Irish Medical Association, 64, 398.

Hrabar, A., Soos, E., Egri-Hecimovic, E. \& VesenjakHiRJAN, J. (1971) Formation of new enzootic foci of $Q$ fever in Croatia. Journal of Hygiene, Epidemiology and Immunology, 15, 52.

Johnson, D.W. (1966) Epidemiology of Q fever in Queensland: a 7-year survey. Medical Journal of Australia, 1, 121.

Johnson, N.E. \& KADULL, P.J. (1966) Laboratory-acquired $Q$ fever: a report of fifty cases. American Journal of Medicine, 41, 391.

LeNNeTte, E.H. \& Welsh, H.H. (1951) Q fever in California.
X. Recovery of Coxiella burneti from the air of premises harboring infected goats. American Journal of Hygiene, $\mathrm{D}$ 54, 44.

MacCallum, F.O., Marmion, B.P. \& Stoker, M.G.P. (1949) $Q$ fever in Great Britain: isolation of Rickettsia burneti from an indigenous case. Lancet, ii, 1026.

MCKIEL, J.A. (1964) $Q$ fever in Canada. Canadian MedicaT Association Journal, 91, 573.

MARMion, B.P. \& STOKER, M.G.P. (1950) Q fever in Greato Britain. Epidemiology of an outbreak. Lancet, ii, 611.

MARmion, B.P. \& Stoker, M.G.P. (1958) The epidemiology@ of $\mathbf{Q}$ fever in Great Britain. An analysis of the findings and some conclusions. British Medical Journal, 2, 809.

Marmion, B.P., Stoker, M.G.P., McCoy, J.H., Malloch, $\vec{O}$ R.A. \& MOORE, B. (1953) Q fever in Great Britain. Ananalysis of sixty-nine sporadic cases with a study of the $\vec{\omega}$ prevalence of infection in humans and cows. Lancet, $\mathbf{i}, 503$.

RobBins, F.C., GAULD, R.L. \& WARNER, F.B. (1946) Q fevę in the Mediterranean area: report of its occurrence in 3 Allied troops. II. Epidemiology. American Journal of Hygiene, 44, 23.

Sellers, R.F. \& Herniman, K.A.J. (1972) The effects of spraying on the amounts of airborne foot and mouth disease virus present in loose boxes. Journal of Hygiene, or 70, 551 .

ShePARD, C.C. \& HuEbNeR, R.J. (1948) $Q$ fever in Los Angeles county: description of some of its epidemiological features. American Journal of Public Health, 38, 781.

STOKER, M.G.P. \& MARMION, B.P. (1955) Isolation of Rickettsia burneti from the Tick Haemaphysalis punctata Journal of Hygiene, 53, 322.

Stoker, M.G.P., Brown, R.D., KetT, F.J.L., Collings, $\stackrel{\oplus}{+}$ P.C. \& MARMion, B.P. (1955) Q fever in Britain. Isolati\&n $\vec{\theta}$ of Rickettsia burneti from placenta and wool of sheep $\ln _{\omega}$ an endemic area. Journal of Hygiene, 53, 313.

TigertT, W.D., Benenson, A.S. \& Gochenour, W.S. (19) Airborne Q fever. Bacteriological Reviews, 25, 285.

TopPING, N.H., ShePaRd, C.C. \& IRONS, J.V. (1947) Q fever in the United States. I. Epidemiologic studies of an out-O break among stock handlers and slaughterhouse workers.음 Journal of the American Medical Association, 133, 813.

Wagstaff, D.J., Janney, J.H., Crawford, K.L., Dimijian, G.G. \& JosePH, J.H. (1965) Q fever studies in Maryland.응 Public Health Reports, 80, 1095.

Welsh, H.H., Lennette, E.H., Abinanti, F.R. \& Winn, J.F. (1951) $Q$ fever in California. IV. Occurrence of Coxiella burneti in the placenta of naturally infected sheep. Public Health Reports, 66, 1473. 